\title{
Biological Characteristics of Trichogramma pretiosum and Trichogramma acacioi (Hym.: Trichogrammatidae), Parasitoids of the Avocado Defoliator Nipteria panacea (Lep.: Geometridae), on Eggs of Anagasta kuehniella (Lep.: Pyralidae)
}

\author{
Dirceu Pratissoli ${ }^{1}$, José Cola Zanuncio ${ }^{2 *}$, Ulysses Rodrigues Vianna ${ }^{2}$, Josimar Souza \\ Andrade $^{2}$, Luiz Carlos Marozzi Zanotti ${ }^{1}$ and Alexandre Faria da Silva ${ }^{1}$ \\ ${ }^{1}$ Departamento de Fitotecnia; Centro de Ciências Agrárias; Universidade Federal do Espírito Santo; 29500-000; \\ dirceu@npd.ufes.br; Alegre - ES - Brazil. ${ }^{2}$ Departamento de Biologia Animal; BIOAGRO; Universidade Federal \\ de Viçosa; 36571-000; zanuncio@ufv.br; ulyssesvianna@insecta.ufv.br; Viçosa - MG - Brazil
}

\begin{abstract}
The objective of this investigation was to study Trichogramma pretiosum and T. acacioi (Hymenoptera: Trichogrammatidae), parasitoids of the avocado defoliator Nipteria panacea (Lepidoptera: Geometridae) on the eggs of the alternative host Anagasta kuehniella (Lepidoptera: Pyralidae) aiming to use them for biological control of this pest in avocado orchards. The cubic model presented better adjustment for duration of the life cycle of $\mathrm{T}$. pretiosum and T. acacioi with the host A. kuehniella which shows that development rate of these species increases with temperature within the range tested. The number of individuals of both Trichogramma species emerged per egg from this host was higher than one. The quadratic model was significant for viability of $\mathrm{T}$. pretiosum and $\mathrm{T}$. acacioi. This parameter was more affected by extreme temperatures and higher emergence rates of adults of both parasitoids species occurred at temperatures of 20,25 and $30^{\circ} \mathrm{C}$.
\end{abstract}

Key words: Avocado, Trichogramma, alternative host, mass rearing

\section{INTRODUCTION}

The avocado (Persea americana Mill.) world production has been approximately 1.2 million tons per year and Brazil is the fourth largest producer but its production is still low. However, avocado production could be higher due to adequate climate and soil for this culture what could meet domestic demand and exports to Mercosul countries especially Argentina and Uruguay (Donadio, 1995).
Avocado represents an alternative for agriculture diversification in the Highlands of the State of Espirito Santo, Brazil where the area cultivated with this fruit increased from 100 hectares to more than 2,000 hectares in 1995 with an annual production over 5,000 tons (Teixeira et al., 1996). Avocado tree presents many insect pests (Donadio, 1995). The expansion of this culture and the indiscriminate use of chemical products against eventual pests in the State of Espírito Santo have contributed to the appearance of Nipteria panacea

\footnotetext{
Author for correspondence
} 
Tierry-Mieg (Lepidoptera: Geometridae) as a defoliator of avocado trees. However, avocado pests and especially $N$. panacea need to be controlled based on ecological criteria with the association of cultural, biological and chemical methods (Pratissoli, 1995). Three main pests of avocado are controlled with insecticides in California but biological control can reduce the number of spraying (Donadio, 1995). On the other hand, such pests have been controlled with biological methods in South Africa and Israel (Donadio 1995). Trichogramma platneri Nagakartti (Hymenoptera: Trichogrammatidae) was imported from California and used against two Geometridae defoliators of avocado trees. Other Trichogramma species are used against 69 key pests in 34 cultures of 30 countries in 32 million hectares, what shows their importance for biological control (Wajnberg and Hassan, 1994). However, the success of biological control with Trichogramma species depends on basic studies on host, temperature, plant architecture and phenology, searching area, wind and chemicals such as insecticides which could affect searching behavior of these organisms (Goodenough and Witz, 1985).

Temperature is the most important physical factor affecting biological aspects such as reproduction type, parasitism (fecundity), duration of development, emergence rate and the longevity of insects (Stern and Bowen, 1963; Butler Júnior and López, 1980; Harrison et al., 1985; Noldus, 1989). Studies on biological and thermal requirements showed that duration of development of Trichogramma species are inversely related to temperature increase (Butler Jr. and López, 1980; Harrison et al., 1985; Miura and Kobayashi, 1993), but such effects depend on species or lineages of Trichogramma (Bleicher and Parra, 1989). Trichogramma minutum Riley presents better development at $32^{\circ} \mathrm{C}$; Trichogramma pretiosum at $30^{\circ} \mathrm{C}$; Trichogramma dendrolini Matsumura between 23 and $25^{\circ} \mathrm{C}$ and Trichogramma chilonis Ishii at $20^{\circ} \mathrm{C}$ (Calvin et al., 1984; Miura and Kobayashi, 1993). These parasitoids can develop between 18 and $30^{\circ} \mathrm{C}$ (Butler Júnior and López, 1980; Harrison et al., 1985; Pak and Heiningen, 1985) but it can be drastically reduced at temperatures below $17^{\circ} \mathrm{C}$ (Butler Júnior and López, 1980; Pak and Heiningen, 1985) and above $32^{\circ} \mathrm{C}$ (Butler Jr. and López, 1980; Pak and
Heiningen, 1985; Gross, 1988; Cabello and Vargas, 1989). Higher temperatures can increase mortality (Gross, 1988; Cabello and Vargas, 1989) and it can affect sex rate of Trichogramma species (Bowen and Stern, 1966).

The objective of this work was to study biological characteristics of the $N$. panacea parasitoids $T$. pretiosum and $T$. acacioi on the eggs of the alternative host Anagasta kuehniella Zeller (Lepidoptera: Pyralidae) aiming to use them in programs of biological control of this pest in avocado orchards.

\section{MATERIALS AND METHODS}

Trichogramma populations L8 and Tapera were obtained from eggs of $N$. panacea (Pratissoli and Fornazier, 1999). Both populations were maintained in the Laboratory of Entomology of the CCAUFES with eggs of the alternative host $A$. kuehniella. Population L8 was identified as $T$. acacioi and Tapera as $T$. pretiosum. The experiment started with newly emerged $T$. acacioi and $T$. pretiosum females individualized with eggs of the alternative host $A$. kuehniella in glass tubes of $3.5 \mathrm{~cm} \times 0.5 \mathrm{~cm}$ closed with plastic PVC film. These females were fed with droplets of honey deposited in the internal part of each tube. An identified blue card $(3.5 \mathrm{~cm} \times 0.5 \mathrm{~cm})$ with 40 eggs of A. kuehniella turned unviable after 50 minutes under a germicidal lamp (Parra and Zucchi, 1997) was put each on 20 tubes and parasitoid species were maintained at the temperatures of $15,20,25,30$ and $35 \pm 1^{\circ} \mathrm{C}$. Parasitism was allowed during 24 hours and parasitoid females were removed under stereoscopic microscope after this period and tubes (containing the card with parasitized eggs) were maintained in aclimatized chambers. The duration of development cycle, the percentage of emergence (viability), and number of individuals of parasitoids per host egg were determined for both Trichogramma species in the morning and in the afternoon, at approximately the same time hour.

Host eggs with a hole made by Trichogramma adults were counted to evaluate emergence rate of these parasitoids. Number of individuals of parasitoids per host egg was evaluated by counting their number emerged from each lot of host eggs. 



Figure 1 - Developmental period (days) from egg to adult of Trichogramma pretiosum (A) and Trichogramma acacioi (B) (Hymenoptera: Trichogrammatidae) on eggs of Anagasta kuehniella (Lepidoptera: Pyralidae) under different temperatures. $70 \pm 10 \%$ R.H. and photofase of 14 hours. 
The experiment was developed in a completely randomized design and results were submitted to variance and regression analysis at the temperatures of $15,20,25,30$ and $35 \pm 1{ }^{\circ} \mathrm{C}$.

\section{RESULTS AND DISCUSSION}

The cubic model was significant and it showed the best fit to adjust duration of development cycle of $T$. pretiosum and $T$. acacioi with the host $A$. kuehniella (Fig 1). This model showed that development rate of these parasitoids increased with thermic elevation, what means that the period from egg to adult increased with temperature decrease. This result represented a similar pattern for insects and it resembled those of Butler Júnior and López (1980), Harrison et al. (1985), Bleicher and Parra (1989) and Pratissoli (1995).
Number of individuals of $T$. pretiosum and $T$. acacioi per egg of A. kuehniella was higher than one with similar results at all temperatures (Table 1). T. pretiosum produced one individual per egg of Scrobipalpuloides (= Tuta) absoluta Meyrick (Lepidoptera: Gelechiidae) at different temperatures (Pratissoli, 1995) but this number could vary with the host because this species presented higher number of individuals per egg of Phthorimaea operculella Zeller (Lepidoptera: Gelechiidae) at $25^{\circ} \mathrm{C}$. It was possible that differences on parasitism rate could also be related to characteristics of host eggs because parasitism rate of $T$. pretiosum was higher on A. kuehniella than on S. cerealella (Gomes, 1997). For this reason, it was possible that physical and chemical characteristics of host eggs were important factors affecting this trait.

Table 1 - Number of individuals of Trichogramma pretiosum and Trichogramma acacioi (Hymenoptera: Trichogrammatidae) per egg of Anagasta kuehniella (Lepidoptera: Pyralidae) under different temperatures. $70+$ $10 \%$ R.H. and fotofase of 14 hours.

\begin{tabular}{ccc}
\hline Temperature $\left({ }^{\circ} \mathbf{C}\right)$ & $\begin{array}{c}\text { Trichogramma } \\
\text { pretiosum }\end{array}$ & Trichogramma acacioi \\
\hline 15 & $1.05 \mathrm{aA}$ & $1.02 \mathrm{aA}$ \\
20 & $1.03 \mathrm{aA}$ & $1.03 \mathrm{aA}$ \\
25 & $1.03 \mathrm{aA}$ & $1.01 \mathrm{aA}$ \\
30 & $1.01 \mathrm{aA}$ & $1.02 \mathrm{aA}$ \\
35 & $1.02 \mathrm{aA}$ & $1.02 \mathrm{aA}$
\end{tabular}

${ }^{\mathrm{I}}$ Means followed by the same capital letter in the column or small letter in the line do not differ between themselves by the test of Tukey at $5 \%$ probability level

The quadratic model was significant and also showed the best fit for viability of $T$. pretiosum and T. acacioi (Fig 2) what showed that viability from egg to adult of these parasitoids varied with temperature. Viability of $T$. pretiosum and $T$. acacioi was more affected by extreme temperatures with higher emergence rate for both parasitoids species at 20,25 and $30^{\circ} \mathrm{C}$ which was similar to results of Pratissoli (1995) with the hosts $S$. absoluta and $P$. operculella. Similar results were also obtained with higher emergence rate for eight Trichogramma lineages between 20 and $30^{\circ} \mathrm{C}$ (Anunciada, 1983) while emergence rate of T. galloi was lower at $18^{\circ} \mathrm{C}$ (Cônsoli and Parra, 1991). Emergence rate of Trichogramma atopovirilia Oatman and Platner and $T$. pretiosum was also affected by temperatures below $20^{\circ} \mathrm{C}$ but this effect could vary because Bleicher and Parra
(1989) showed similar viability for several Trichogramma species in higher temperatures (18 to $32^{\circ} \mathrm{C}$ ).

Period from egg to adult of $T$. pretiosum and $T$. acacioi was inversely proportional to temperature increase with lower emergence rate of both Trichogramma species at 15 and $35^{\circ} \mathrm{C}$. Number of individuals of $T$. pretiosum and T. acacioi per egg of the alternative host A. kuehniella was near one. This number was not affected by temperature but sex rate of both parasitoid species was affected by temperature with higher values at $15^{\circ} \mathrm{C}$. 




$\mathrm{Y}=-341.71+32.3988 \mathrm{Temp}-0.584840 \mathrm{Temp}^{2}$

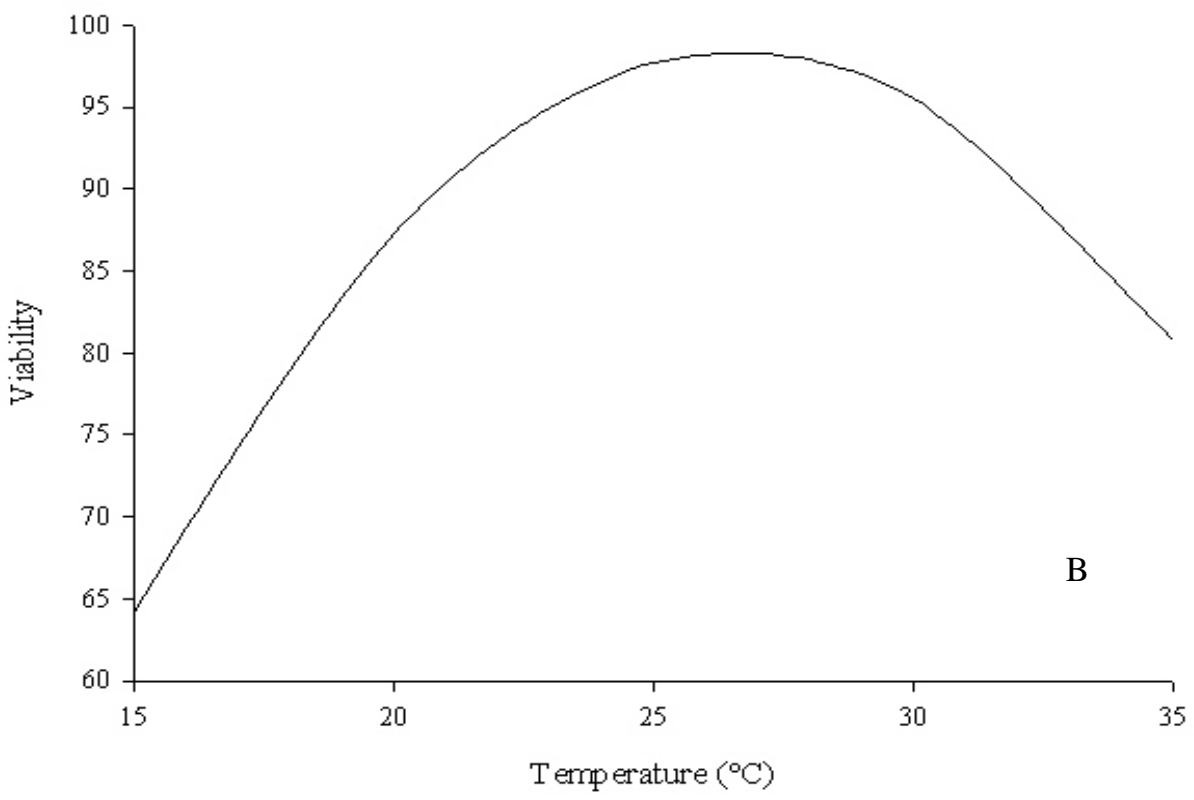

Figure 2 - Viability from egg to adult (\%) of Trichogramma pretiosum (A) and Trichogramma acacioi (B) (Hymenoptera: Trichogrammatidae) on eggs of Anagasta kuehniella (Lepidoptera: Pyralidae) under different temperatures. $70 \pm 10 \%$ R.H. and photofase of 14 hours. 


\section{ACKNOWLEDGEMENTS}

We thank "Conselho Nacional de Desenvolvimento Científico e Tecnológico (CNPq)", "Coordenação de Aperfeiçoamento de Pessoal de Nível Superior (CAPES)" and "Fundação de Amparo à Pesquisa do Estado de Minas Gerais (FAPEMIG)".

\section{RESUMO}

O objetivo deste trabalho foi estudar a biologia de Trichogramma pretiosum Riley e Trichogramma acacioi Brun, Moraes and Soares (Hymenoptera: Trichogrammatidae), parasitóides de Nipteria panacea Thierry-Mieg (Lepidoptera: Geometridae), sobre ovos do hospedeiro alternativo Anagasta kuehniella Zeller (Lepidoptera: Pyralidae), visando à utilização desses inimigos naturais em programas de controle biológico dessa praga em pomares de abacateiro. O modelo cúbico foi significativo e apresentou o melhor ajuste para a duração do ciclo biológico de $T$. pretiosum e de $T$. acacioi no hospedeiro $A$. kuehniella, mostrando que a velocidade de desenvolvimento dessas espécies aumenta com a elevação da temperatura. O número de indivíduos por ovo de A. kuehniella, para as duas espécies de Trichogramma foi maior que um. O modelo quadrático apresentou melhor ajuste para a razão sexual de $T$. pretiosum e $T$. acacioi, com maior emergência de fêmeas desses parasitóides a $15^{\circ} \mathrm{C}$ e aumento da produção de machos com aumento da temperatura. O modelo quadrático foi, também, significativo para a viabilidade de $T$. pretiosum e T. acacioi, a qual foi mais afetada por temperaturas extremas, enquanto a taxa de emergência desses parasitóides foi maior nas temperaturas de $20^{\circ}, 25^{\circ}$ e $30^{\circ} \mathrm{C}$.

\section{REFERENCES}

Anunciada, L. A. (1983). Escolha do oófago Trichogramma para o controle de Mythimna unipuncta. Tese de Doutorado, Universidade do Açores, Ponta Delgada, Portugal.

Bleicher, E.; Parra, J. R. P. (1989), Espécies de Trichogramma parasitóides de Alabama argillacea. I. Biologia de três populações. Pesquisa Agropecuária Brasileira, 24, 929-940.
Bowen, W. R.; Stern, V. M. (1966), Effect of temperature on the production of males and sexual mosaics in a uniparental race of Trichogramma semifumatum (Hymenoptera: Trichogrammatidae). Annals of the Entomological Society of America, 59, 823-834.

Buttler Júnior, G. D.; Lopez, J. D. (1980), Trichogramma pretiosum: Development in two hosts in relation to constant and fluctuating temperatures. Annals of the Entomological Society of America, 73, 671-673.

Cabello, T.; Vargas, P. (1989), Resistance to high temperatures in the developmental stages of Trichogramma cordubensis Vargas and Cabello and T. pintoi Voegelé (Hym.: Trichogrammatidae). Boletin de Sanidad Vegetal de Plagas, 15, 263-266.

Calvin, D. D.; Knapp, M. C.; Welchm, S. M.; Poston, F. L.; Elzinga, R. J. (1984), Impact of environmental factors on Trichogramma pretiosum reared on Southwestern corn borer eggs. Environmental Entomology, 13, 774-780.

Cônsoli, F. L.; Parra, J. R. P. (1991), Biology of $T$. galloi at constant and fluctuating temperatures. Paper presented at $12^{\text {th }}$ International Plant Protection Congress, Rio de Janeiro, Rio de Janeiro.

Donadio. L. C. (1995), Abacate para exportação: aspectos técnicos da produção. 2. ed. Brasilia : Frupex.

Goodenough, J. L.; Witz, J. A. (1985), Modeling augmentative releases of Trichogramma pretiosum. The Southwestern Entomologist, 8, 169-189.

Gomes, S. M. (1997), Comparação de três hospedeiros alternativos para criação e produção massal de Trichogramma pretiosum Riley (1879) e Trichogramma galloi Zucchi (1988). Dissertação de Mestrado, Escola Superior de Agricultura "Luiz de Queiros", Piracicaba - SP, Brasil.

Gross, H. R. (1988), Effect of temperature, relative humidity, and free water on the number and normalcy of Trichogramma pretiosum Riley (Hym.: Trichogrammatidae) emerging from eggs of Heliothis zea (Boddie) (Lep.: Noctuidae). Environmental Entomology, 17, 470-475.

Harrison, W. W.; King, E.G.; Ouzts, J.D. (1985), Development of Trichogramma exiguum and $T$. pretiosum at five temperature regimes. Environmental Entomology, 14, 118-121.

Miura, K.; Kobayashi, M. (1993), Effect of temperature on the development of Trichogramma chilonis Ishii (Hymenoptera: Trichogrammatidae), an egg parasitoid of the diamondback moth. Applied Entomology and Zoology, 28, 393-396.

Noldus, L. P. J. J. (1989), Semiochemicals, foraging behaviour and quality of entomophagous insects for biological control. Journal of Applied Entomology, 108, 425-451. 
Pak, G. A.; Heiningen, T. C. (1985), Behavioral variations among strains of Trichogramma spp.: adaptability to field temperature conditions. Entomologia Experimentalis et Applicata, 38, 3-13.

Parra, J. R. P.; Zucchi, R.A. (1997) Trichogramma e o controle biológico. São Paulo : FEALQ. 324 pp.

Pratissoli, D. (1995), Bioecologia de Trichogramma pretiosum Riley, 1879, nas traças Scrobipalpuloides absoluta (Meyrick, 1917) e Phthorimaea operculella (Zeller, 1873), em tomateiro. Tese de Doutorado, Escola Superior de Agricultura "Luiz e Queiroz", Piracicaba - SP.

Pratissoli, D.; Fornazier, M. J. (1999), Ocorrência de Trichogramma acacioi Brun, Moraes and Soares (Hym.: Trichogrammatidae) em ovos de Nipteria panacea Thierry-Mieg (Lep.: Geometridae), um geometrídeo desfolhador do abacateiro. Anais da Sociedade Entomológica do Brasil, 28, 347-349.

Stern, V. M.; Bowen, W. (1963), Ecological studies of Trichogramma semifumatum with notes on Apanteles medicaginis, and their suppression of Colias eurytheme in Southern California. Annals of the Entomological Society of America, 56, 358-372.

Teixeira, C. P.; Fornazier, M. J.; Ventura, J. A.; Cerqueira, A. (1996), A abacaticultura no Estado do Espírito Santo. Paper presented at $14^{\text {th }}$ Congresso Brasileiro de Fruticultura 1996, Curitiba, Paraná.

Wajnberg, E.; Hassan, S. A. (1994), Biological control with egg parasitoids. British Library, Wallingford. pp. 286. 